Research Article

\title{
Inquiry-based learning and the pre-requisite for its use in science at school: A meta-analysis
}

\author{
Manuela Heindl \\ Technical University Dresden, Dresden, Germany
}

\begin{abstract}
The purpose of this meta-analysis was to determine the pre-requisite for and the efficacy of inquiry-based learning to improve academic performance in contrast to traditional lessons. Randomised studies with pre- and post-test design with control and treatment groups were filtered with a priori inclusion criteria and analysed in Review Manager (2014). Out of the results in ERIC 13 studies were found, which show that inquiry-based learning can be more effective when the students and the teachers are well-prepared (Messner, 2009). The results of this meta-analysis of the studies between 2011 and 2017, as well as the theory in the literature, show that there is a positive effect size towards its regular implementation in primary $(d=0.67)$ and secondary schools $(d=0.81)$. Therefore, there should be more inquiry-based learning lessons taught in science and in other school subjects and the pre-requisite according to Messner (2009) have an effect of $d=0.88$.
\end{abstract}

Keywords: Inquiry based learning; Science; Meta-analysis; Academic achievement; Pre-requisite

Article History: Submitted 21 December 2018; Revised 2 April 2019; Published online 23 May 2019

\section{Introduction}

Inquiry-based learning has been officially introduced in German-speaking countries since Meyer's (2003) definition of it. The sequence of teaching in inquiry-based learning differs from traditional lessons (Sembill, 1996). According to Huber (2003) this teaching style includes: developing the questions and hypotheses, choosing and executing methods, examining and presenting the results. The learners autonomously work in an interdisciplinary project because they have to combine different subjects. This can be a problem, especially for younger learners. According to Kuhn and Pease (2008), as there are differences in acquiring skills, it is advisable to analyse the outcomes for primary and secondary students separately. In scientific disciplines, the method of inquiry-based learning has several links to the general scientific approach and, therefore, can also be used in numerous publications (ERIC, 2017). However, Kirschner, Sweller and Clark (2006) also point out that this way of learning can be too demanding from a cognitive perspective and can thus lead to frustration and possibly to lower academic achievement. The extent to which this learning style affects the performance of primary and secondary school students (Gagné \& Driscoll, 1988) will be examined in this meta-analysis. Messner (2009), who defined the term "inquiry-based learning",

Address of Corresponding Author

Manuela Heindl, Technical University Dresden, Faculty of Education, Weberplatz 5, 01062 Dresden, Germany.

$\triangle$ mpsoak@gmail.com

0000-0002-1436-4388

How to cite: Heindl, M. (2019). Inquiry-based learning and the pre-requisite for its use in science at school: A meta-analysis. Journal of Pedagogical Research, 3(2), 52-61. 
also considers a preparatory unit for teachers and/or students as the pre-requisite of this learning style. Therefore, the following research questions are at the centre of this meta-analysis:

1. What is the level of effect on academic performance in primary or secondary school classes of inquiry-based learning in science compared to traditional lessons?

2. What is the effect size of inquiry-based learning on academic performance in existing studies, if the pre-requisite recommended by Messner (2009), a preparatory unit for inquiry-based learning for teachers and/or students, is satisfied?

\subsection{Inquiry-based Learning versus Traditional Lessons}

In traditional lessons, unlike in inquiry-based learning, the teacher is at the centre of the process (Gasser, 2004). The National Research Council (1996) in America publishes studies on how teachers should carry out these lessons. The current term "inquiry-based learning" is more precise than the original term "inquiry". It has been enhanced with different learning styles and best practice examples. In German-speaking countries, the implementation took place later. Messner (2009) described this form of learning as a preliminary stage for scientific work which is projectoriented, research/ discovery-based and problem-oriented. Essential components of Reitinger's (2013) definition are cognitive interest, exploration, hypothesising, choice of method, discourse and publication of results. Such pre-scientific activity will be referred to as "inquiry-based learning" in this paper. Since experimentation is understood as a way of solving problems, inquiry-based learning is seen as essential for gaining scientific knowledge (Hammann, Phan, \& Bayrhuber, 2008). Therefore, it is mostly represented in biology, physics and chemistry (ERIC, 2017).

\subsection{Preparation Unit and Age}

According to Messner (2009), preparation for inquiry-based learning should be a pre-requisite for a successful project implementation. He recommends a practice-oriented coaching or training unit, where the learners and/or the teachers are prepared for this teaching concept. In their longitudinal study, Kuhn and Pease (2008) identified a preparatory unit of three years as beneficial in their study for primary school pupils. Although secondary school pupils were not specifically prepared for inquiry-based learning through the use of a preparatory unit, their approach outperformed primary school learners in the following areas: structured, logical and thoughtful approach, quantitative analysis and meaningful understanding of the data. However, they struggled to achieve a successful project outcome. Thus, a preparation unit for younger learners was useful because their scientific skills were not properly developed and were being improved in order to be well-prepared for their future lessons. To what extent age plays a role should, therefore, not be neglected in this work. As the older learners benefited from a preparation unit in relation to the outcome of the project, it is necessary to examine the age groups separately.

\subsection{Academic performance}

Gagné and Driscoll (1988) understand the performance that can be observed as the result of learning. In order to quantify the learning success of inquiry-based learning sessions, pupils are usually tested on what they have learned in the lesson. Although Erpenbeck and Rosenstiel (2003) presented more than 40 competence measurement procedures in their manual, this work focusses on studies that use tests at the end of the inquiry-based lesson because this way of testing is predominantly used in publications (Abd-El-Khalick et al., 2004). The positive effect of inquirybased learning in general (Hetmanek, Knogler, \& Chu, 2017; Reitinger, 2013) and on the academic performance in school has been empirically proven in several studies (Chang, Sung, \& Lee, 2003, Fischer, Mitchell, \& Alamo, 2007, Friedman \& Heafner, 2007; Guisti, 2008; Ross, Morrisson, \& Lowther, 2010). 


\section{Method}

\subsection{Review of the Literature}

The effect size was calculated from studies in which pupils in the control group were taught in a traditional lesson and in which pupils in the treatment group were engaged in an inquiry-based learning lesson. The search was conducted using ERIC (2017) with the following keywords: "inquiry learning, pretest, posttest, effectiveness, outcome" and using Google Scholar (2017) adding the words "inquiry-based learning, -flipped -game -maps -deaf -blind". The time limit was drawn after the international project PRIMAS (2011) in order to present a current effect size. Additionally, it was possible to include European studies since a common definition of inquirybased learning emerged after 2011 (Reitinger, 2013). All previous publications, as well as all studies that did not fit into the topic, that did not test pupils' academic performance or that did not have a control group or were published without a peer review, were excluded.

\subsection{Selection Criteria}

After reviewing the studies, they were analysed to determine if they fitted the selection criteria such as quantitative studies, articles from journals and dissertations since 2011, research results from primary and secondary schools in science, studies with an internal consistency of Cronbach's a> 0.6 (Hinton, Brownlow, McMurray, \& Cozens, 2004, p. 365), the treatment group was taught according to the definition by Reitinger (2013) and the control group to the definition of Gasser (2004, p. 141).

\subsection{Included Studies}

A total of 338 studies were found (319 studies from Google Scholar, 18 articles from ERIC and one study from other sources, a book by Reitinger (2013)) of which 261 were excluded after review of the abstract and a further 65 after reviewing the full text. Reasons for this decision were: they didn't meet the inclusion criteria, the learners were older than 18 years or the data was inappropriate for a meta-analysis. No duplicate publications were found. 6 Studies from ERIC and 7 from Google Scholar provided a complete data set.

Table 1 shows the studies with the year of publication and the country of investigation and the primary or secondary level. Furthermore, the maximum number of 13 points according to Luborsky, Singer and Luborsky (1975) is given in brackets for the quality of how the study was carried out. These are the examined studies for the meta-analysis: Abdi (2014), Barak, Ashkar and Dori (2011), Barthlow (2011), Chiang, Yang and Hwang (2014), Dijk and Lazonder (2013), Ergül, Simsekli, Calis, Özdilek, Göcmencelebi and Sanli (2011), Hasan (2012), Hashim, Ababkr and Eljack (2015), Maxwell, Lambeth and Cox (2015) , Meij, Meij, \& Harmsen (2015), Njoroge, Changeiywo and Ndirangu (2014), as well as Omokaadejo (2015).

\subsection{Coding}

The coding was carried out according to:

- the names of the authors with publication year and country

- the age of the learners in secondary (S) or primary/elementary (E) school

- the quality characteristics of the study (Luborsky, Singer, \& Luborsky, 1975), and

- a preparatory unit or a practical training session for inquiry-based learning session according to the definition of Messner (2009), in which teachers and/or students are prepared to carry out or participate successfully in an inquiry-based learning lesson. 
Table 1.

Characteristics of included studies

\begin{tabular}{|c|c|c|c|c|c|}
\hline Author & Year & Country & $\begin{array}{c}\text { Elementary (E)/ } \\
\text { Secondary (S) }\end{array}$ & $\begin{array}{l}\text { Preparation to } \\
\text { Messner (2009) }\end{array}$ & (quality) \\
\hline Abdi & 2014 & Iran & $\mathrm{E}$ & - & 12 \\
\hline Barak & 2011 & Israel & $\mathrm{E}$ & - & 13 \\
\hline Barthlow & 2011 & USA & $S$ & Yes & 13 \\
\hline Chiang & 2014 & Taiwan & $\mathrm{E}$ & - & 12 \\
\hline Dijk & 2013 & Netherlands & $S$ & - & 12 \\
\hline Ergül & 2011 & Turkey & E & Yes & 12 \\
\hline Ergül & 2011 & Turkey & $S$ & Yes & 13 \\
\hline Hasan & 2012 & Dubai & $S$ & - & 12 \\
\hline Hashim & 2015 & Nigria & $S$ & - & 13 \\
\hline Maxwell & 2015 & USA & $\mathrm{E}$ & - & 12 \\
\hline Meij & 2014 & Netherlands & $\mathrm{E}$ & - & 12 \\
\hline Njoroge & 2015 & Kenia & $S$ & Yes & 13 \\
\hline Omokaadejo & 2015 & Nigeria & $S$ & - & 13 \\
\hline
\end{tabular}

\subsection{Calculation of the results}

A random-effect meta-regression was calculated using the statistical programme Review Manager (2014). Entering the mean and the standard deviation for the treatment and control groups provided a weighted effect size and a CI of $95 \%$ for each study and subgroup. There were no missing data in the calculation. The Q-test shows the heterogeneity of the studies. The mean difference and IV for the inverse variance were chosen as an output mode because academic performance is a continuous dependent variable (Higgins \& Green, 2011). Cohen (1988) interprets a value of $<0$ as negative, a value of $0.0-0.2$ as none, from $0.21-0.5$ as a small, from $0.51-0.8$ as an average and from 0.8 as a large effect.

\subsection{Studies}

Eight studies were conducted in secondary and five in primary schools. Inquiry-based learning is carried out according to the definition of Messner (2009) and Reitinger (2013) and described as follows in the studies: learners should engage in self-directed activities (Abdi, 2014), gather and discuss results from the following (virtual) experiments on: electrical circuit (Njoroge, Changeiywo, \& Ndirangu, 2014), physical constructs (Meij, Meij, \& Harmsen, 2015), atomic constellations (Barthlow, 2011), underwater scenarios (Chiang, Yang, \& Hwang, 2014), prey species (Hasan, 2012), cycle of nature (Barak, Ashkar, \& Dori, 2011), greenhouse effect (Dijks \& Lazonder, 2013) and in science in general (Ergül, Simsekli, Calis, Özdilek, Göcmencelebi, \& Sanli, 2011) A standardised test has been used in the studies by Abdi (2014), Hasen (2012), Njoroge, Changeiywo and Ndirangu (2014) and Ergül, Simsekli, Calis, Özdilek, Göcmencelebi and Sanli (2011).

\subsection{Quality of Results}

To ensure the quality of the results of the procedure, an 18-item checklist according to the QUOROM method by Moher et al. (1999) was added to Appendix 1. The studies of Abdi (2014), 
Chiang, Yang and Hwang (2014), Dijk and Lazonder (2013), Ergül, Simsekli, Calis, Özdilek, Göcmencelebi and Sanli (2011), Hasan (2012), and Max and Meij, Meij and Harmsen (2015) achieved only 12 instead of 13 quality points for the quality of their performance according to Luborsky, Singer and Luborsky (1975) because the sample size was smaller than in the other studies. A funnel plot (as in Figure 1) can detect a possible publication bias that affects the quality of the research.

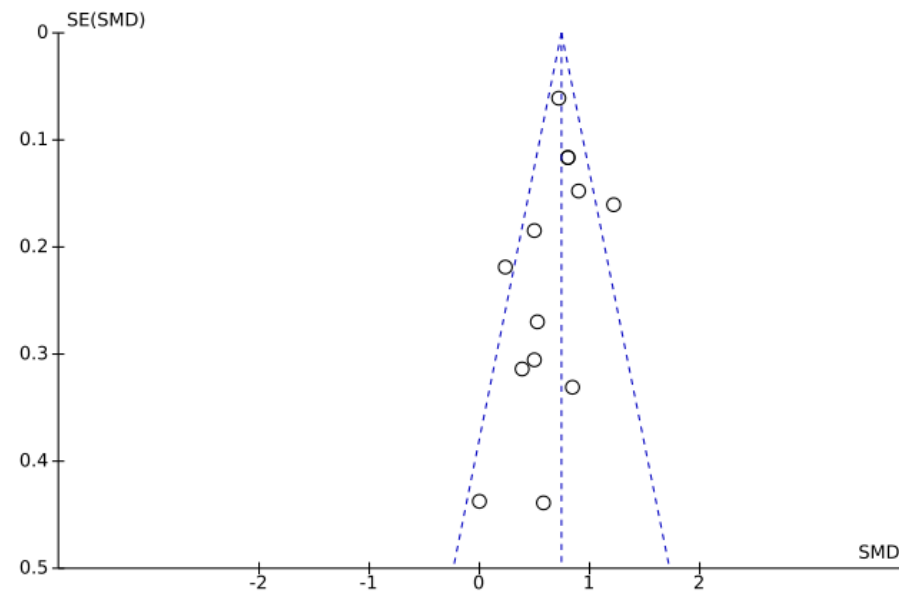

Figure 1. Funnel plot

If the funnel plot is symmetrical and similar to a pyramid, the bias is lower (Suchmacher \& Geller, 2012). According to Ressing, Blettner and Klug (2009), the appearance of studies in the lower left of the triangle, which are visible in this research funnel plot, is an indication of no bias.

\section{Results}

The following forest plots represent the results and show the first author, the year of publication, the country, primary/elementary (E) or secondary (S) school, the quality of the study in brackets, the mean values, the standard deviation for the treatment (experimental) and the control group, the weight of the study, the heterogeneity, the number of the sample size and the individual and the overall effect size below the studies with a confidence interval of $95 \%$. A random-effect model was chosen because the studies suggest heterogeneity.

Table 2 shows the mean differences in pupils' academic performance in inquiry-based learning versus traditional lessons.

Table 1.

Forest plot for all studies

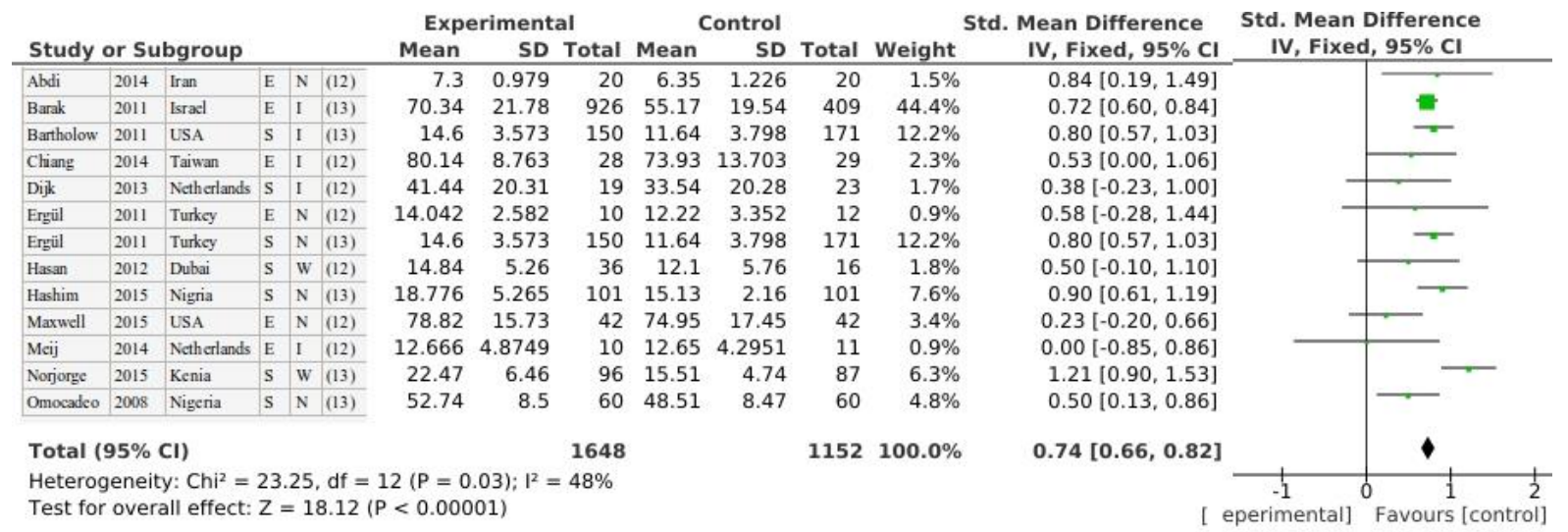


The positive values of the mean differences indicate a higher level of academic performance in inquiry-based learning lessons as opposed to traditional lessons. $\mathrm{I}^{2}$ is $<50 \%$ in this study. Higgins, Thompson, Deeks and Altmann (2003, p. 559) consider this value of heterogeneity to be low and thus the weighted effect size can be interpreted.

The following results in Table 3 were calculated to answer the research question regarding the learners' age.

Table 3.

Forest plot for studies in secondary schools

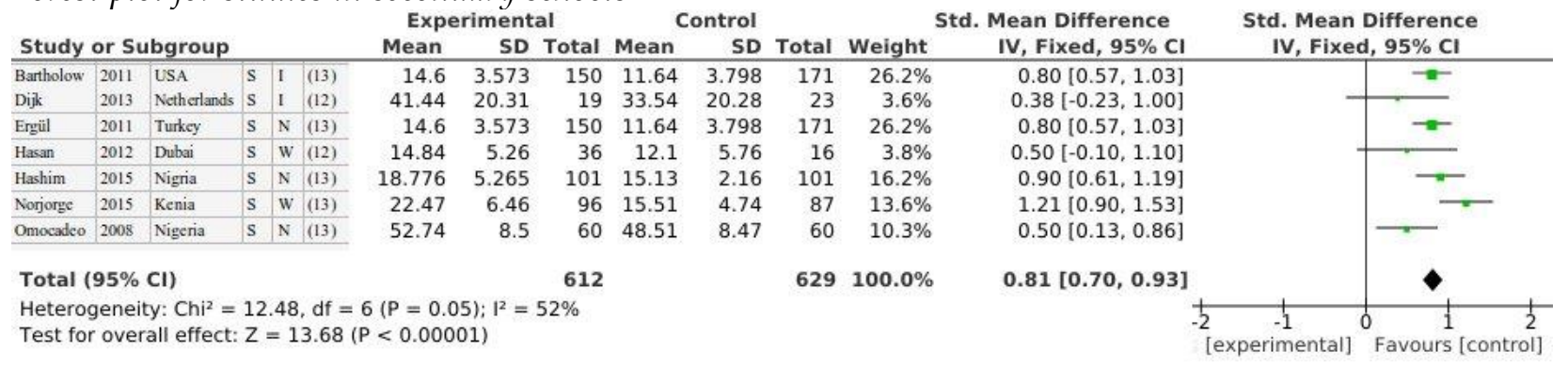

An effect size of 0.81 is calculated for the studies carried out in secondary schools (TG $\mathrm{n}=612, \mathrm{KG} \mathrm{n}=629,0.81$ with $95 \% \mathrm{CI}$ of [0.70, 0.93], $\mathrm{p}=0.001)$. These seven studies are slightly above the $50 \%$ threshold of homogeneity $\left(\mathrm{Chi}^{2}=12.48, \mathrm{df}=6(\mathrm{p}=0.05), \mathrm{I}^{2}=52 \%\right)$.

In contrast, the effect size of 0.67 is lower in the studies in primary schools (TG $\mathrm{n}=1036$, $\mathrm{KG} \mathrm{n}=523,0.67$ with $95 \% \mathrm{CI}$ of $[0.56,0.78], \mathrm{p}=0.001)$ than in secondary schools. These six studies are homogeneous ( $\left.\mathrm{Chi}^{2}=7.54, \mathrm{df}=5(\mathrm{p}=0.18), \mathrm{I} 2=34 \%\right)$. The effect sizes are 0.81 for secondary schools and 0.67 for primary schools. This outcome is gathered from studies found between 2011 and 2017 which compare the learners' academic performance between inquiry-based learning and traditional lessons. The outcome of these studies suggest that inquiry-based learning is a suitable teaching method in primary and secondary schools in order to increase pupils' academic performance in science.

Table 4.

Forest plot for studies in primary schools

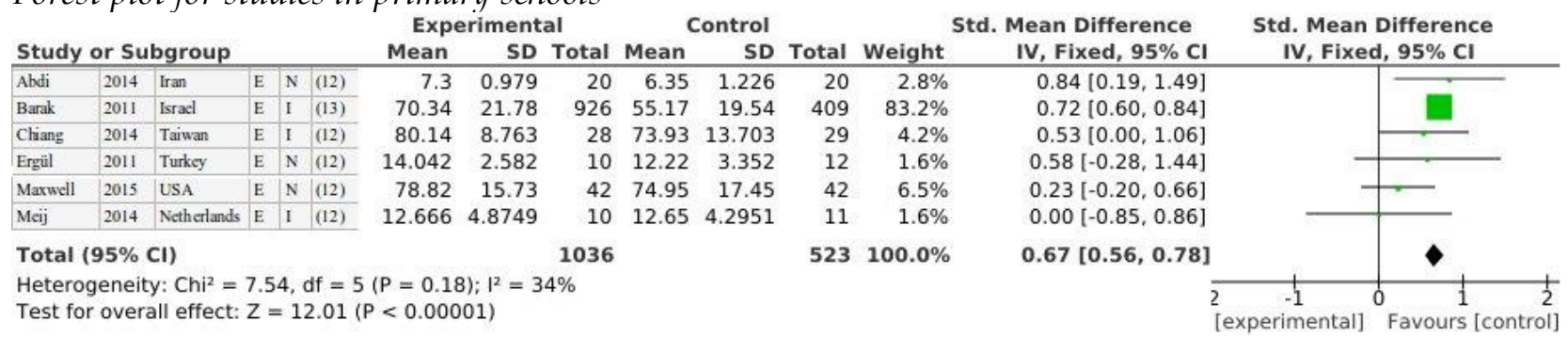

According to Messner (2009, p. 25ff), a preparatory unit for teachers/and for students in inquiry-based learning settings is required such as that used in the study by Njoroge, Changeiywo and Ndirangu (2014). A preparatory unit for teachers was carried out in a study by Barthlow (2011). There was also an introduction for teachers and learners in the study by Ergül, Simsekli, Calis, Özdilek, Göcmencelebi and Sanli (2011). The effect size of 0.88 (TG n = 406, KG n = 441, 0.88 with $95 \%$ CI of $[0.73,1.02], p=0.001)$ of these studies is very high and they are homogeneous $\left(\mathrm{Chi}^{2}=5.73, \mathrm{df}=3(\mathrm{p}=0.13), \mathrm{I}^{2}=48 \%\right)$. 
Table 5.

Forest plot for studies with a preparation unit

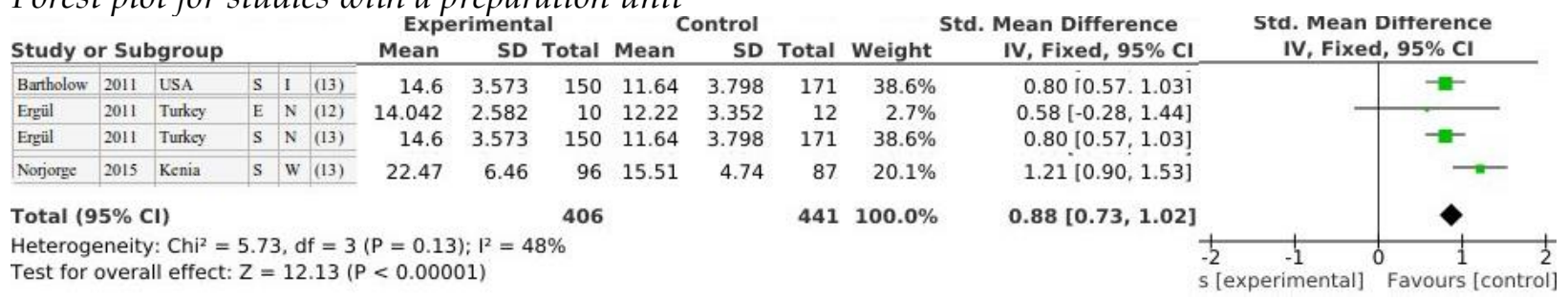

The effect size of the studies found between 2011 and 2017, which compared pupils' academic performance in inquiry-based learning with traditional lessons was 0.67 in primary schools and 0.81 in secondary schools. If a preparation unit was carried out, a pre-requisite recommended by Messner (2009), the effect size of these studies was 0.88 . One reason for this high value could be that inquiry-based learning is a common method in the scientific disciplines (ERIC, 2017) and it is more established than in other school subjects.

\section{Tendency, Comment and Conclusion}

The examined studies show a favorable tendency towards improved learning as a result of inquiry-based learning over traditional lessons. The effect size of inquiry-based learning is higher in secondary than in primary education. The highest effect size was seen when a preparation unit for the inquiry-based learning lesson is present. An area of future investigation in this field would be to examine the effect sizes of inquiry-based learning lessons with digital tools and how they can be successfully used in this process. This meta-analysis encourages teachers to offer inquiry-based learning sessions at school and in school subjects other than science. This is how researchers should be able to find sufficient opportunities in the future to explore all areas, especially in artistic and creative school subjects. This meta-analysis shows that there are insufficient studies carried out with a pre- and post-test design and with control and experimental groups. Studies are rare in primary schools and therefore more research should be carried out in this field. The limitation of this study was the small number of examined studies and of studies which showed negative results. For that reason, dissertations were also included and they showed no or little effect sizes, which provides more balance to this research. Consequently, a random-effect model was used because it also takes unpublished outcomes into consideration. This work corresponds to other small-scale (Furtak, Seidel, Iverson, \& Briggs, 2012) meta-studies that are valuable in gaining insight in this research field overall. An implementation of inquiry-based learning at a young age is therefore justified. Since learners should take on more and more responsibility for their learning success and process (Bastiaens, Schrader, \& Deimann, 2016), educators are required to try out new forms of learning in order to meet the demands of society. Inquiry-based learning supports science education. If learners and teachers have an opportunity to receive a preparatory introduction in accordance with the recommendations of Messner (2009) to this pre-scientific teaching method, it is even more successful, especially in primary schools.

Acknowledgments: I would like to express my deep gratitude to Professor Dr. Thomas Köhler and Prof. Dr. Bruri Triyono for their useful and constructive recommendations on this project. It provided me with very valuable insights. I would also like to thank Gary Barnett for proofreading the article and suggesting improvements. 


\section{References}

Abd-El-Khalick, F., BouJaoude, S., Duschl, R., Lederman, N. G., Mamlok-Naaman, R., Hofstein, A., \& Tuan, H. (2004). Inquiry in science education: International perspectives. Science Education, $88(3), 397-419$.

Abdi, A. (2014). The Effect of Inquiry-based Learning Method on Students' Academic Achievement in Science Course. Universal Journal of Educational Research, 2(1), 37-41.

Barak, M., Ashkar, T., \& Dori, Y. J. (2011). Learning science via animated movies: Its effect on students' thinking and motivation. Computers $\mathcal{E}$ Education, 56(3), 839-846.

Barthlow, M. J. (2011). The Effectiveness of Process Oriented Guided Inquiry Learning to Reduce Alternate Conceptions in Secondary Chemistry. Liberty University, VA. Retrieved from http://digitalcommons.liberty.edu/doctoral/442

Bastiaens, T. J., Schrader, C., \& Deimann, M. (2016). Lehren und Lernen in der Wissensgesellschaft. Hagen: Fakultät für Kultur- und Sozialwissenschaften - FernUniversität in Hagen. Studienbrief 33080.

Chang, K.-E., Sung, Y.-T., \& Lee, C.-L. (2003). Web-based collaborative inquiry learning. Journal of Computer Assisted Learning, 19(1), 56-69.

Chiang, T. H. C., Yang, S. J. H., \& Hwang, G.-J. (2014). An Augmented Reality-based Mobile Learning System to Improve Students' Learning Achievements and Motivations in Natural Science Inquiry Activities in Natural Science. Educational Technology \& Society, 17(4), 352-365.

Cohen, J. (1988). Statistical power analysis for the behavioral sciences. Hillsdale, NJ: Erlbaum.

Dijk, A. M., \& Lazonder, A. W. (2016). Scaffolding students' use of learner-generated content in a technology-enhanced inquiry learning environment. Interactive Learning Environments, 24(1), 194-204.

Ergül, R., Simsekli, Y., Calis, S., Özdilek, Z., Göcmencelebi, S., \& Sanli, M. (2011). The effects of inquiry-based science teaching on elementary school students' science process skills and science attitudes. Bulgarian Journal of Science and Education Policy, 5(1), 48-68.

ERIC. (2017). ERIC - Education Resources Information Center. Retrieved October 20, 2017, from https://eric.ed.gov/

Erpenbeck, J., \& Rosenstil, L. (2003). Handbuch Kompetenzmessung. Stuttgart: Schäffer-Poeschl Verlag.

Fischer, J., Mitchell, R., \& Alamo, J. (2007). Inquiry-Learning with WebLab: Undergraduate Attitudes and Experiences. Journal of Science Education and Technology, 16(4), 337-348.

Friedman, A. M., \& Heafner, T. L. (2007). "You think for me, so I don't have to". Contemporary Issues in Technology and Teacher Education, 7(3), 199-216.

Furtak, E. M., Seidel, T., Iverson, H., \& Briggs, D. C. (2012). Experimental and Quasi-Experimental Studies of Inquiry-Based Science Teaching: A Meta-Analysis. Review of Educational Research National Research Council [NRC], 82(3), 300-329.

Gagné, R. M., \& Driscoll, M. P. (1988). Essentials of learning for instruction. New York: Prentice Hall.

Gasser, P. (2014). Neue Lernkultur: eine integrative Didaktik. Aarau: Bildung Sauerländer.

George, D., \& Mallery, P. (2003). SPSS for Windows step by step : a simple guide and reference, 11.0 update. Boston: Allyn and Bacon.

Google Scholar. (2017). Google Scholar. Retrieved October 20, 2017, from https://scholar.google.com/

Guisti, B. M. (2008). Comparison of Guided and Open Inquiry Instruction in a High School Physics Classroom. Brigham Young University. Retrieved from http://scholarsarchive.byu.edu/etd

Hammann, M., Phan, T. H., \& Bayrhuber, H. (2008). Experimentieren als Problemlösen. In Kompetenzdiagnostik (pp. 33-49). Wiesbaden: VS Verlag für Sozialwissenschaften.

Hasan, A. S. H. (2012). The effects of guided inquiry instruction on students' achievement and understanding of the nature of science in environmental biology course. Dubai: British University. Retrieved from https://bspace.buid.ac.ae/bitstream/1234/395/1/100026.pdf 
Hashim, A., El, T., Ababkr, S., Sid, N., \& Eljack, A. (2015). Effects of inquiry based science teaching on junior secondary school students' academic achievements. SUST Journal of Humanities, 16(1), 156-169.

Hetmanek, A., Knogler, M., \& CHU. (2017). Forschendes Lernen. Retrieved from https://www.clearinghouse.edu.tum.de/wp-content/uploads/2017/07/CHU_KR-

5_Lazonder-Harmsen-2016_Forschendes-Lernen.pdf

Higgins, J., Thompson, S., Deeks, J., \& Altmann, D. (2003). Measuring inconsistency in metaanalyses. BMJ, 327(7414), 55-60.

Higgins, J., \& Green, S. (2011). Summary of meta-analysis methods available in RevMan. Retrieved March 10, 2018, from http://handbook-51.cochrane.org/chapter_9/table_9_4_a_summary_of_meta_analysis_methods_available_in.htm

Hinton, P. R., Brownlow, C., McMurray, I., \& Cozens, B. (2004). SPSS explained. London: Routledge.

Huber, L. (2003). Forschendes lernen in Deutschen hochschulen. In A. Obolenski \& H. Meyer (Eds.), Forschendes Lernen (pp. 15-36). Bad Heilbrunn: Klinkhardt.

Kirschner, P. A., Sweller, J., \& Clark, R. E. (2006). Why minimal guidance during instruction does not work. Educational Psychologist, 41, 75-86.

Kuhn, D., \& Pease, M. (2008). What needs to develop in the development of inquiry skills? Cognition and Instruction, 26(4), 512-559.

Luborsky, L., Singer, B., \& Luborsky, L. (1975). Comparative studies of psychotherapies. Archives of General Psychiatry, 32(8), 995-1008.

Maxwell, D. O., Lambeth, D. T., \& Cox, J. T. (2015). Effects of using inquiry-based learning on science achievement for fifth-grade students. Asia-Pacific Forum on Science Learning and Teaching, 16(21), 1-31.

Meij, H., Meij, J., \& Harmsen, R. (2015). Animated pedagogical agents effects on enhancing student motivation and learning in a science inquiry learning environment. Educational Technology Research and Development, 63(3), 381-403.

Messner, R. (2009). Forschendes Lernen aus pädagogischer Sicht. In R. Messner (Ed.), Schule forscht (pp. 15-30). Hamburg: Ed. Körber-Stiftung.

Meyer, H. (2003). Skizze eines Stufenmodells zur Analyse von Forschungskompetenzen. In A. Obolenski \& M. Meyer, HilbertMeyer (Eds.), Forschendes Lernen (pp. 99-117). Bad Heilbrunn: Klinkhardt.

Moher, D., Cook, D. J., Eastwood, S., Olkin, I., Rennie, D., \& Stroup, D. F. (1999). Quality of Reporting of Meta-analyses. Lancet, 354(9193), 1896-900.

National Academies of Sciences Engineering and Medicine. (2000). Inquiry and the National Science Education Standards. Washington, D.C.: National Academies Press.

Njoroge, G. N., Changeiywo, J. M., \& Ndirangu. (2014). Effects of inquiry-based teaching approach on Secondary School Students' achievement and motivation in Physics in Nyeri County, Kenya. International Journal in Academic Research in Education Review, 2(1), 1-16.

Omokaadejo L. (2015). Effects of inquiry method on academic performance of chemistry students in senior secondary schools in Kaduna state. Ahmadu Bello Univsersity Zaria. Retrieved from http:// kubanni.abu.edu.ng:8080/jspui/handle/123456789/7312

PRIMAS. (2011). Promoting inquiry-based learning in mathematics and science education across Europe Policy. Freiburg. Retrieved from http://www.primas-project.eu/

Rathgeb, T., \& Behrens P. (2014). KIM-Studie. Stuttgart. Retrieved from https://www.mpfs.de/fileadmin/files/Studien/KIM/2014/KIM_Studie_2014.pdf

Reitinger, J. (2013). Forschendes Lernen. Immenhausen bei Kassel: Prolog-Verlag.

Ressing, M., Blettner, M., \& Klug, S. J. (2009). Systematische Übersichtsarbeiten und Metaanalysen. Deutsches Ärzteblatt International, 106(27), 456-463.

Review Manager. (2014). Review Manager Version 5.3. Copenhagen: The Cochrane Collaboration. Retrieved from http://community.cochrane.org/tools/review-production-tools/revman-5 
Ross, S. M., Morrison, G. R., \& Lowther, D. L. (2010). Educational technology research past and present. Contemporary Educational Technology, 1(1), 17-35.

Sembill, D. (1992). Problemlösefahigkeit, Handlungskompetenz und emotionale Befindlichkeit: Zielgroßen forschenden Lernens. Göttingingen: Hogrefe.

Suchmacher, M., \& Geller, M. (2012). Practical Biostatistics. London: Academic Print. 